Brit: J. industr, Med., 1952, 9, 282.

\title{
AN ANALYSIS OF ABSENCE UNDER A SCHEME OF PAID SICK LEAVE
}

\author{
BY \\ R. B. BUZZARD and W. J. SHAW \\ From the Medical Research Council Unit of Applied Psychology, Cambridge
}

(RECEIVED FOR PUBLICATION JUNE 23, 1952)

In September, 1948, a scheme for paid sick leave was introduced for industrial workers in Government employment. By this scheme an employee who is absent from work because of illness receives his full flat rate of pay for as long as 13 weeks in any year. National Insurance benefit and any further allowances from other Government sources are deducted from this pay. All employees are entitled to receive sick pay once they have completed 26 weeks' Government service. If an employee has had five years' Government service, he is entitled to a further 13 weeks' absence on half pay. No one may receive more than one year's sick pay in any four years. Absences of three days only are not paid ; absences of four days receive one day's pay, but if a man is absent for a period of five days or more he receives sick pay for the whole period of absence. A doctor's certificate is required as evidence of incapacity.

After this scheme was introduced there was a sharp increase in sick absence. The increase was more than had been expected and was maintained into the year 1950. The scheme was to have been revised in September, 1950, but by June it was clear that too little was known about it, and in July, 1950, we were asked to make this investigation.

In 1949 the sick pay scheme applied to some 330,000 employees in 42 Government departments : 275,000 were employed in the four largest departments, the Admiralty, the War Office, the Air Ministry, and the Ministry of Supply. We decided to confine the study, initially at least, to these four departments, and visited their headquarters to discover what information was already available. Their statistics revealed that recorded sick absence as a whole appeared to have doubled. By far the larger proportion of that increase was due to longer rather than to shorter absences, particularly to absences of four weeks or more.

The increase of recorded sick absence was spread fairly evenly throughout the main disease groups.

The increase was real ; that is to say it was not to any extent accounted for by a reduction in absences of other kinds. (For example, there was a slight reduction in absences recorded as "casual absence ", as is to be expected when there is greater incentive to produce a medical certificate, but this reduction was negligible when taken in relation to the total increase in sick absence.)

There remained, however, several important questions which could not be answered by a study of headquarters statistics and made necessary a sample survey in industrial establishments. The questions we posed, and which are analysed in our results, were :-

(1) What proportion of the population records sick absence? (2) How is the increase in sick absence distributed among people of different ages? Is the present supposedly high rate of absence chiefly due to the employment of more elderly workers? (3) The headquarters' statistics included long-term absences for which sick pay had been exhausted. To what extent do these long unpaid absences and the policy of Government establishments of retaining men on the books account for the present high rates? (4) To what extent is the present rate due to the sick absence of the registered disabled ? (5) Do new entrants have a higher rate of sick absence than those of longer service? (6) Are the sick absence rates of those in the more responsible and skilled jobs less than those of the unskilled worker? (7) Is the rate for those on "incentive" pay (who revert to flat rates for sick pay) less than that of the time worker? (8) Do workers take excessive sick absence before discharge or retirement? (9) How does the sick absence of industrial workers compare with that of non-industrial workers whose sick pay scheme is of long standing?

An exploratory study was first made to discover the best ways of collecting the information required, 
and, after a standard method had been devised, 28 further establishments were visited between January 15 and March 29, 1951.

On each visit the method of collecting the information was explained and arrangements made for any modifications required for the particular establishment. When it appeared that the collection of any item of information might be difficult, owing to local variations in record keeping, we asked that it should be omitted rather than run the risk of inaccuracy. We asked for no information to be supplied except where we were satisfied, after inspecting the records, that it could be furnished accurately and without undue difficulty. On each visit the sick pay scheme was discussed with the executive and with workers' representatives.

Our information was collected by means of a

\section{STANDARD FORM}

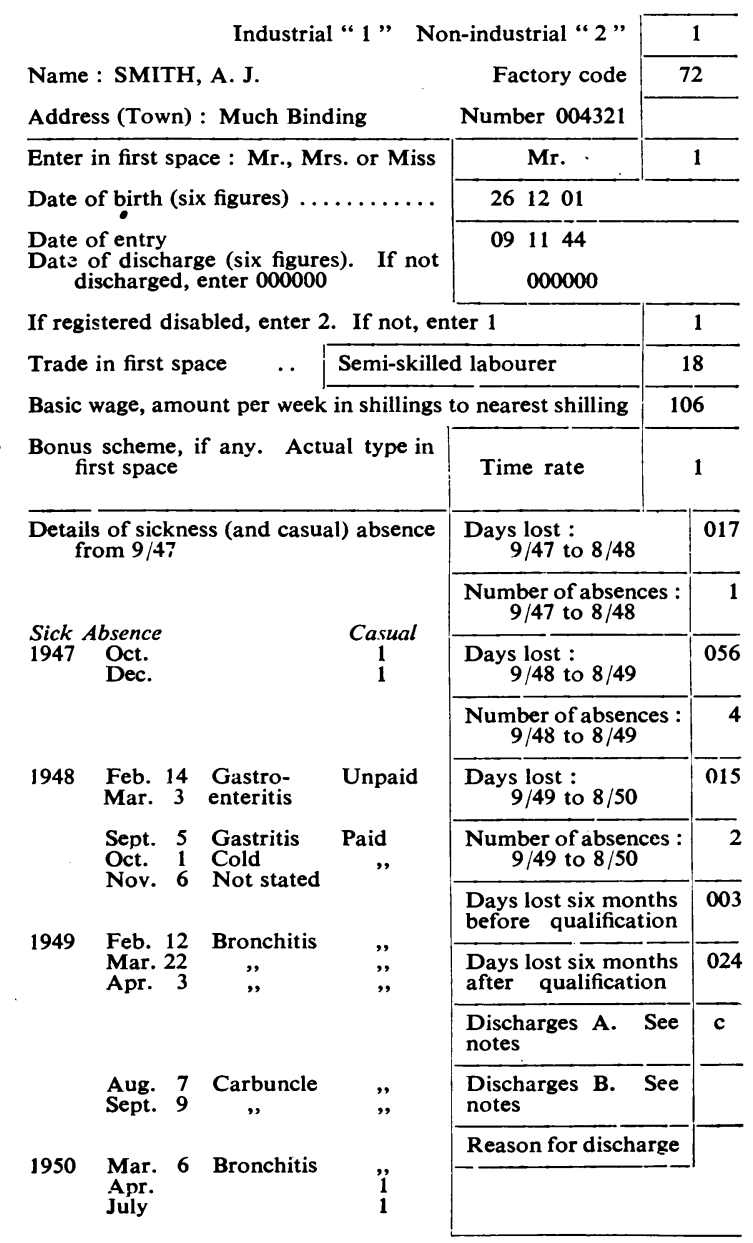

standard form designed to contain a summary of an individual's sick absence from the period September, 1947, to August, 1950, and to contain other necessary facts such as his age, date of entering the establishment, type of work, wage, etc. Where an individual had entered after September, 1947, his sick absence record was taken from the date of entry. Wage, grade, and occupation were taken as at August 31, 1950.

In most cases the bulk of our information came from the wages record card. In some cases, where it was more convenient and we were satisfied of their accuracy, other sources were used. Supplementary information came from personnel records.

\section{Sampling}

It would have imposed too heavy a task to have asked for true samples of strengths of establishments in each of the three years we were studying. Our main sample was therefore taken from the men employed in the establishments at the time of our visit. In the tables given in this report it must be realized that the rates shown for the years September, 1947, to August, 1948, and September, 1948, to August, 1949, are not intended to represent the actual sick absence rates in these years; they are the rates only for employees who remained in the establishments up to the time of our visits. In our tables, also, men are classified according to their ages in the year 1950 so that the rates given for the year 1947 to 1948 are for men who were two years younger at that time. In choosing establishments we aimed at a sample which would be representative of the four departments, and also of large and small establishments and of different geographical areas.

We wished to obtain sufficient numbers from the smaller establishments to enable comparisons to be made between establishments or groups of establishments. This usually involved asking for a sample of one in four of the total strength. At the larger establishments it appeared that the amount of work entailed in making returns for a sample of one in four would have been prohibitive, and the size of the samples was therefore reduced. This means that the larger establishments are under-represented in our sample, but we do not believe that this will bias the statistics contained in this report, unless it is later shown that the rates of sick absence in large and small establishments vary significantly. Samples were drawn from alphabetical or numerical lists of current employees. In all, some 8,000 records were included in our tabulations and, for most purposes, the number is sufficient. In the extreme age groups, however, the numbers are too few in some of our tables for comparisons at this age to be significant. 


\section{Sources of Error}

Two operations were required to complete the standard form. The first was the direct copying of an individual's sick absence record and certain personal details from his wages sheet, sick pay card, or other sources. The second was the calculation of yearly totals of absence, and totals for six months before and six months after a man was eligible to receive sick pay. Each form was then examined and simple errors of calculation were corrected and then re-checked by another examiner. Wherever the errors were not obvious clerical slips and we could not make corrections ourselves with absolute confidence, the form was returned to the establishment for re-examination. To estimate the reliability of our own corrections, all doubtful forms from three establishments were returned for re-examination; where the errors were simple matters of calculation of such things as dates of qualifying for sick pay, our theoretical calculations of the date did not differ from the corrections made by the establishment by more than one or two days. When sick pay was shown as exhausted but the date did not tally with our own calculations, the record was again suspect and returned for re-examination. This method of checking brought to light some forms where there had been errors in the recorded details of sickness as well as in the calculation of totals, and it must be assumed that there were other forms in which details had not been recorded accurately. However, from the number of forms which had to be returned to any one establishment, we have a crude indication of the probable accuracy of the clerical work done there and of the probable accuracy of our returns.

We believe that the hidden errors of copying would be largely errors of omission. It would be possible to omit an instance of recorded sickness but unlikely that additional instances of sickness would be invented, especially where the diagnosis had also to be entered. In establishments where the clerical work did not seem to have been very accurate, it is possible that the overall figures of absence given us would be lower than the true ones. This would become important when comparing one establishment with another. But it seems likely that such omissions would be random, and that the differences between the large groups which form the basis of this report would be unaffected. The same conclusions apply to other types of error in the forms themselves.

Another possibility of error arises with the transfer of the information from our form to the Hollerith punch card. Again we have a check only when the error results in an apparent impossibility.
After sorting we had, for instance, 15 cards with ages recorded as from 1 to 10 years or from 90 to 100. This is a small number in some 8,000 , but indicates the probability of other errors of punching. But again there is no reason to suppose that such errors are not distributed at random and, with the large numbers involved, our comparisons should remain unaffected.

We conclude that our data are reliable for the purposes to which they have been put.

\section{Results}

This report is confined to the male population which forms the large majority of the total.

The average number of days lost per employee is the most convenient way of expressing sick absence rates, but it can be very misleading when used in comparing small groups of people. In such cases, the chance inclusion or exclusion of even one or two people with very long absences will greatly alter the average rates. In the tables we have also given the average length of absence for each occasion of sickness, the number of occasions of sickness for every 100 employees, and the percentage of the population which records any sick absence in the periods under consideration. All tables refer to working days lost.

(1) What Proportion of the Population Records Sick Absence? Table 1 shows that the percentage of the population with one or more occasions of sick absence in the year increased from 27 in 1947-48 to 46 in 1949-50. It is worth noting that over half the population still recorded no sick . absence in the latter year.

(2) How Is the Increase Distributed Among Different Ages? Table 1 also shows that in both $1947-48$ and in 1949-50 the average number of days lost rises with age. But the increase during $1948-50$ is relatively the same for each age group, except for the men under 30 for whom the increase is less. Among the men under 25 there has been a greater increase in the number who record sickness absence, but very few of this age group recorded sickness absence before paid sick leave was introduced.

The absences for men of 56 and over have been extracted from the total, and the average number of days lost for the remainder is shown. The overall average is then reduced from 13.4 to 11.7 in 1948-49 and from 14.1 to 12.5 in 1949-50. Although the average absence of the older men is high, the numbers involved are not sufficient to alter the general average to any great extent. It cannot be said that the present rates are to any major extent due to the more elderly employees. 
TABLE 1

SICK ABSENCE OF TOTAL SAMPLE (MALE INDUSTRIALS)

\begin{tabular}{|c|c|c|c|c|c|c|c|c|c|c|c|c|c|c|c|}
\hline \multirow[b]{2}{*}{$\begin{array}{c}\text { Age } \\
\text { at } \\
1950\end{array}$} & \multicolumn{5}{|c|}{ September, 1947-August, 1948} & \multicolumn{5}{|c|}{ September, 1948-August, 1949} & \multicolumn{5}{|c|}{ September, 1949-August, 1950} \\
\hline & No. & $\begin{array}{c}\text { Average } \\
\text { Days } \\
\text { Lost }\end{array}$ & $\begin{array}{c}\text { Average } \\
\text { Length } \\
\text { of } \\
\text { Absence }\end{array}$ & $\begin{array}{l}\text { Absences } \\
\text { per 100 } \\
\text { Workers }\end{array}$ & $\begin{array}{c}\text { Per- } \\
\text { centage } \\
\text { with } \\
\text { Sickness }\end{array}$ & No. & $\begin{array}{c}\text { Average } \\
\text { Days } \\
\text { Lost }\end{array}$ & $\begin{array}{l}\text { Average } \\
\text { Length } \\
\text { of } \\
\text { Absence }\end{array}$ & $\begin{array}{l}\text { Absences } \\
\text { per 100 } \\
\text { Workers }\end{array}$ & $\begin{array}{c}\text { Per- } \\
\text { centage } \\
\text { with } \\
\text { Sickness }\end{array}$ & No. & $\begin{array}{c}\text { A verage } \\
\text { Days } \\
\text { Lost }\end{array}$ & $\begin{array}{l}\text { Average } \\
\text { Length } \\
\text { of } \\
\text { Absence }\end{array}$ & $\begin{array}{c}\text { Absences } \\
\text { per 100 } \\
\text { Workers }\end{array}$ & $\begin{array}{c}\text { Per- } \\
\text { centage } \\
\text { with } \\
\text { Sickness }\end{array}$ \\
\hline \multirow{3}{*}{$\begin{array}{l}61 \text { and } \\
\text { over } \\
56-60 \\
51-55 \\
46-50 \\
41-45 \\
36-40 \\
31-35 \\
26-30 \\
21-25 \\
20 \text { and } \\
\text { under }\end{array}$} & 579 & $6 \cdot 4$ & $14 \cdot 2$ & 44.9 & 31 & 606 & $16 \cdot 6$ & $24 \cdot 3$ & $68 \cdot 0$ & 47 & 629 & $17 \cdot 8$ & $25 \cdot 0$ & $71 \cdot 2$ & 49 \\
\hline & \begin{tabular}{|r|}
735 \\
866 \\
693 \\
626 \\
548 \\
301 \\
242 \\
105 \\
51
\end{tabular} & $\begin{array}{c}6 \cdot 9 \\
5 \cdot 6 \\
5 \cdot 0 \\
4 \cdot 3 \\
3 \cdot 2 \\
4 \cdot 4 \\
4 \cdot 6 \\
4 \cdot 8 \\
(3 \cdot 9)\end{array}$ & $\begin{array}{c}13 \cdot 3 \\
12.0 \\
13.6 \\
12 \cdot 2 \\
9 \cdot 0 \\
10 \cdot 3 \\
12.0 \\
15 \cdot 1 \\
(7 \cdot 4)\end{array}$ & $\begin{array}{c}52 \cdot 1 \\
46 \cdot 9 \\
36 \cdot 6 \\
35 \cdot 1 \\
35 \cdot 8 \\
42 \cdot 5 \\
38 \cdot 0 \\
31 \cdot 4 \\
(52 \cdot 9)\end{array}$ & $\begin{array}{l}32 \\
27 \\
25 \\
24 \\
22 \\
30 \\
25 \\
17 \\
(25)\end{array}$ & $\begin{array}{r}763 \\
891 \\
715 \\
651 \\
574 \\
341 \\
291 \\
163 \\
74\end{array}$ & $\begin{array}{r}18.7 \\
16.0 \\
13.2 \\
10.6 \\
9.5 \\
7.9 \\
10.0 \\
7.5 \\
(6 \cdot 3)\end{array}$ & $\begin{array}{c}24 \cdot 3 \\
23 \cdot 8 \\
21 \cdot 6 \\
17 \cdot 1 \\
16 \cdot 1 \\
14 \cdot 1 \\
14 \cdot 2 \\
13 \cdot 0 \\
(10 \cdot 1)\end{array}$ & $\begin{array}{l}76 \cdot 8 \\
67 \cdot 3 \\
61 \cdot 3 \\
61 \cdot 9 \\
58 \cdot 7 \\
56 \cdot 0 \\
70 \cdot 5 \\
57 \cdot 7 \\
(62 \cdot 2)\end{array}$ & $\begin{array}{c}51 \\
45 \\
42 \\
42 \\
40 \\
39 \\
45 \\
40 \\
(38)\end{array}$ & $\begin{array}{l}796 \\
927 \\
760 \\
704 \\
625 \\
383 \\
373 \\
236 \\
101\end{array}$ & $\begin{array}{c}19.5 \\
15.7 \\
13.3 \\
11.9 \\
10.7 \\
12.9 \\
10.4 \\
9.9 \\
(4.8)\end{array}$ & $\begin{array}{l}25 \cdot 2 \\
22 \cdot 2 \\
20 \cdot 7 \\
19 \cdot 3 \\
16 \cdot 2 \\
18 \cdot 7 \\
13 \cdot 9 \\
16 \cdot 4 \\
(8 \cdot 4)\end{array}$ & $\begin{array}{l}77 \cdot 5 \\
70 \cdot 8 \\
64 \cdot 1 \\
61 \cdot 8 \\
65 \cdot 9 \\
68 \cdot 9 \\
75 \cdot 0 \\
60 \cdot 6 \\
(57 \cdot 4)\end{array}$ & $\begin{array}{l}51 \\
48 \\
44 \\
43 \\
42 \\
45 \\
44 \\
42 \\
(41)\end{array}$ \\
\hline & $\overline{4,746}$ & $5 \cdot 2$ & 12.4 & $42 \cdot 1$ & 27 & $\overline{5,069}$ & 13.4 & $20 \cdot 4$ & $65 \cdot 3$ & 44 & 5,534 & $14 \cdot 1$ & 20.6 & $68 \cdot 7$ & 46 \\
\hline
\end{tabular}

PERCENTAGE INCREASE OF 1949-50 OVER 1947-48

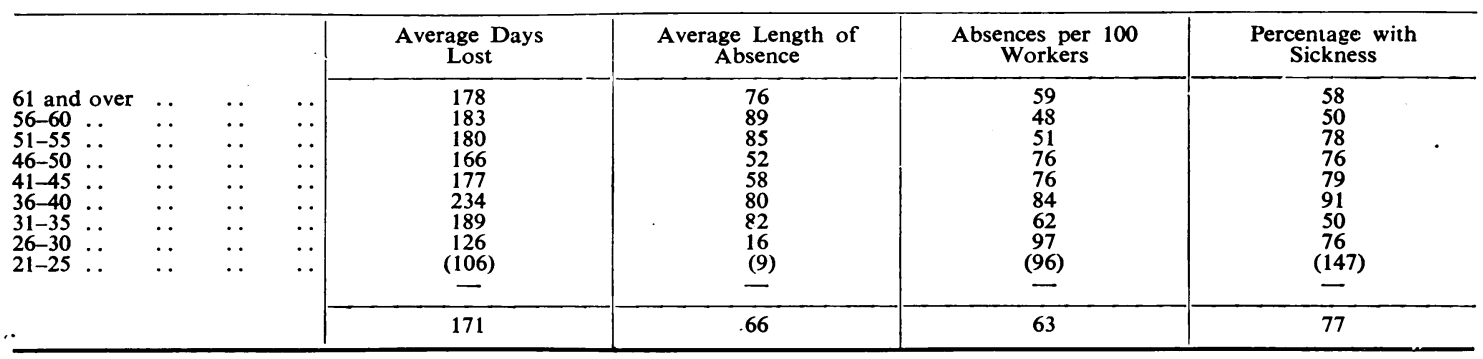

(3) To what Extent Does the Inclusion of Long Term (Unpaid) Sick Absence Account for Apparent High Rates? For all but five establishments our records show the proportion of long absences which are unpaid or at half pay. Table 2 shows the average rates before and after both unpaid and halfpaid absence is extracted. In the year 1949-50 the average number of days lost is reduced from 14.6 to 11.9. (This reduced rate cannot be compared with the rate for $1947-48$, since it is not possible in that year to make a reliable estimate of the absence which would represent unpaid absence under the scheme.) But even after the extraction of unpaid absence, the rate of absence appears formidable compared with that for 1947-48.

(4) To What Extent Is the Present Rate due to the Sick Absence of the Registered Disabled ?-The standard form on which information from establishments was gathered contained a space for entering whether the individual was registered disabled or not. The number of registered disabled represented approximately $7 \cdot 2 \%$ of the total for whom this entry was properly completed. The relative rates of sick absence are shown by the following figures.

\begin{tabular}{|c|c|c|c|c|}
\hline & \multirow{2}{*}{ No. } & \begin{tabular}{|c|} 
Sept., 1947- \\
Aug., 1948
\end{tabular} & \multirow{2}{*}{ No. } & $\begin{array}{l}\text { Sept., 1949- } \\
\text { Aug, 1950 }\end{array}$ \\
\hline & & $\begin{array}{c}\text { Average No. } \\
\text { Days Lost }\end{array}$ & & $\begin{array}{l}\text { Average No. } \\
\text { Days Lost }\end{array}$ \\
\hline $\begin{array}{l}\text { Recorded as registered } \\
\text { disabled }\end{array}$ & 289 & $9 \cdot 1$ & 332 & $25 \cdot 3$ \\
\hline $\begin{array}{l}\text { Recorded as not regi- } \\
\text { stered disabled }\end{array}$ & 3,889 & $5 \cdot 1$ & 4,582 & $13 \cdot 7$ \\
\hline Total population & 4,746 & $5 \cdot 2$ & 5,534 & $14 \cdot 1$ \\
\hline
\end{tabular}

Although the number of registered disabled is too small for exact comparison, two observations can be made. While the rate for the group as a whole is high compared with the rest of the population, the proportion of registered disabled is so low that their exclusion- does not have much effect on the overall rate. The rate for those recorded as not registered disabled is only 0.4 days less than that of the total population in the period 1949-50. Moreover, the registered disabled had higher rates before the scheme was introduced and there is very little difference in the percentage increase on the year before the scheme. It cannot be said that the sick absence of the registered disabled has had any great effect on the present overall rates. 
TABLE 2

ABSENCE AT HALF AND NO PAY

\begin{tabular}{|c|c|c|c|}
\hline \multirow[b]{2}{*}{ Age at 1950} & \multicolumn{3}{|c|}{ September, 1949, to August, 1950} \\
\hline & No. & $\begin{array}{c}\text { Average Days } \\
\text { Lost }\end{array}$ & $\begin{array}{l}\text { Average Days Lost } \\
\text { after Extraction of } \\
\text { Absences on Half } \\
\text { and No Pay }\end{array}$ \\
\hline 61 and over... & 489 & $18 \cdot 5$ & $15 \cdot 3$ \\
\hline $56-60 \ldots$ & 634 & $19 \cdot 7$ & $14 \cdot 7$ \\
\hline $51-55 .$. & 713 & $15 \cdot 8$ & $12 \cdot 7$ \\
\hline $46-50 \ldots$ & 592 & $13 \cdot 4$ & $11 \cdot 1$ \\
\hline $41-45 \ldots$ & 531 & $13 \cdot 5$ & $10 \cdot 6$ \\
\hline $36-40 \ldots$ & 459 & $10 \cdot 3$ & $8 \cdot 5$ \\
\hline $31-35 \ldots$ & 295 & $13 \cdot 2$ & $12 \cdot 2$ \\
\hline $26-30 \ldots$ & 256 & $10 \cdot 5$ & $9 \cdot 9$ \\
\hline $21-25 \ldots$ & 182 & $11 \cdot 5$ & $3 \cdot 7$ \\
\hline 20 and under & 62 & $4 \cdot 5$ & $4 \cdot 4$ \\
\hline Total .. & 4,213 & $14 \cdot 6$ & 11.9 \\
\hline
\end{tabular}

(5) Do New Entrants Have a Higher Rate than Men of Longer Service?-Men who entered after the scheme was introduced had only six months during which they were unable to draw sick pay. We have therefore calculated the rates during the six months before and the six months after they were qualified for sick pay. Rates for six months before and after qualification have also been calculated for men of longer service. With the men of longer service the six months before qualification is the period March to August, 1948, and the six months after qualification is the period September, 1948, to February, 1949; for the new entrants these periods before and after qualification occur at varying times of the year.
For the men of longer service we are always comparing a winter with a summer rate. One would expect, other things being equal, that the group of men with longer service would show a higher rate in the six months after qualification and a larger increase over the six months before. Table 3 gives the position. While the increase is certainly greater in men with longer service, the rates for the middle age groups of the new entrants is higher in the six months after qualification than that of the men with longer service. However, due to the disparity in age distribution, the overall rates for the two groups are much the same.

Without estimating the rates to be expected at different times of the year, it is impossible to state definitely whether or not new entrants have relatively greater sick absence than men of longer service, but the figures suggest that any difference would be small. From this and from the fact that the new entrants represent only a small proportion of the total population, it can be concluded that it would not be worth paying any special attention to this question. There is certainly no evidence on these data to support one of the suggestions made to us that the period of qualifying service should be increased. That would have little effect beyond reducing the total numbers of men eligible for sick pay. It must nevertheless be pointed out that our survey was completed before recruitment under the rearmament programme had properly begun, and, where there has since been a large influx of new labour, possibly recruited at a time when labour was scarce, the above conclusion may not hold true.

(6) Are the Rates of More Responsible and Skilled Workers Less than the Unskilled?-The population

TABLE 3

SICK ABSENCE AND LENGTH OF SERVICE

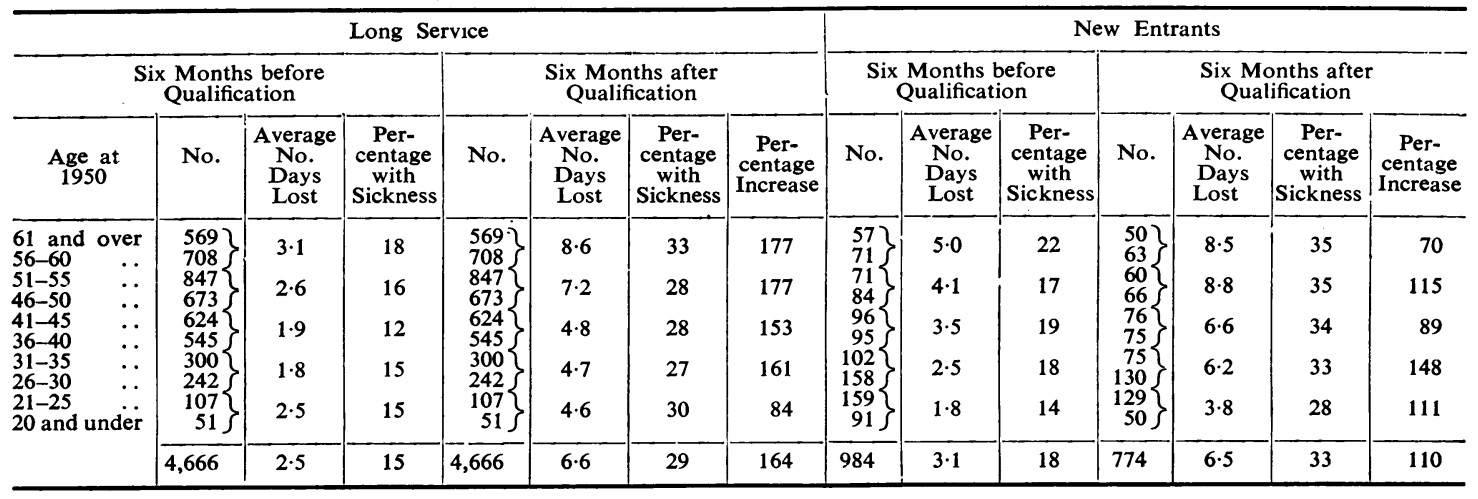

Overall Totals

Six months before qualification ( 5,650 workers) average days lost $=2 \cdot 6$; yearly equivalent $=5 \cdot 2$. Six months after qualification $(5,440$ workers) average days lost $=6 \cdot 6$; yearly equivalent $=13 \cdot 2$. 
was divided into three main trade groups, skilled, unskilled, and miscellaneous :-

Trade Group 1.-This comprises boiler-makers, borers, carpenters, electricians, examiners, fitters, instrument makers, joiners, markers-out, millers, millwrights, setters, shipwrights, ship-fitters, pattern makers, tool and gauge makers, turners, and armourers. These are classed as skilled trades in all four departments.

Trade Group II.-This comprises brush hands, clothing workers, crane drivers, fire brigade men, firemen, labourers (skilled and unskilled), mates, machine hands, M.T. drivers, packers, packing case makers, process workers, slingers, stokers, storemen, and truck drivers. These are classed as unskilled trades.
Trade Group III.-This comprises chasers, inspectors, painters, viewers, and leading hands (whom it is apparently difficult to class as invariably skilled or unskilled), and various miscellaneous trades which, because of their infrequency, were not given separate code numbers on the punch cards. Incomplete forms in which the trade was not given are also grouped here.

Overlookers, leading storemen, and telephone operators were excluded from these groups because men in these trades were entitled to some sick pay before September, 1948. Apprentices and cleaners were also excluded, apprentices because their sick rates were peculiarly low, and cleaners because among them are found many part-time workers.

Table 4 gives the rates for Trade Groups I, II, and III.

TABLE 4

ANALYSIS OF SICKNESS ABSENCE RELATED TO SKILLED AND UNSKILLED TRADE GROUPS

\begin{tabular}{|c|c|c|c|c|c|c|c|c|c|c|c|c|c|c|}
\hline \multicolumn{15}{|c|}{ Trade Group I: Skilled } \\
\hline \multirow[b]{2}{*}{$\begin{array}{c}\text { Age } \\
\text { at } \\
1950\end{array}$} & \multicolumn{5}{|c|}{ September, 1947-August, 1948} & \multicolumn{5}{|c|}{ September, 1949-August, 1950} & \multicolumn{4}{|c|}{ Percentage Increase } \\
\hline & No. & $\begin{array}{l}\text { Aver- } \\
\text { age } \\
\text { Days } \\
\text { Lost }\end{array}$ & $\begin{array}{c}\text { Aver- } \\
\text { age } \\
\text { Length } \\
\text { of } \\
\text { Absence }\end{array}$ & $\begin{array}{c}\text { Absences } \\
\text { per 100 } \\
\text { Workers }\end{array}$ & $\begin{array}{c}\text { Per- } \\
\text { centage } \\
\text { with } \\
\text { Sickness }\end{array}$ & No. & $\begin{array}{l}\text { Aver- } \\
\text { age } \\
\text { Days } \\
\text { Lost }\end{array}$ & $\begin{array}{c}\text { Aver- } \\
\text { age } \\
\text { I_ength } \\
\text { of } \\
\text { Absence }\end{array}$ & $\begin{array}{l}\text { Absences } \\
\text { per } 100 \\
\text { Workers }\end{array}$ & $\begin{array}{c}\text { Per- } \\
\text { centage } \\
\text { with } \\
\text { Sickness }\end{array}$ & $\begin{array}{l}\text { Aver- } \\
\text { age } \\
\text { Days } \\
\text { Lost }\end{array}$ & $\begin{array}{c}\text { Aver- } \\
\text { age } \\
\text { Length } \\
\text { of } \\
\text { Absence }\end{array}$ & $\begin{array}{c}\text { Absences } \\
\text { per } 100 \\
\text { Workers }\end{array}$ & $\begin{array}{c}\text { Per- } \\
\text { centage } \\
\text { with } \\
\text { Sickness }\end{array}$ \\
\hline \multirow{6}{*}{$\begin{array}{c}61 \text { and } \\
\text { over } \\
56-60 \\
51-55 \\
46-50 \\
41-45 \\
36-40 \\
31-35 \\
26-30 \\
21-25 \\
20 \text { and } \\
\text { under }\end{array}$} & \multirow{5}{*}{$\left.\begin{array}{r}68 \\
91 \\
123 \\
135 \\
150 \\
144 \\
85 \\
96 \\
49 \\
4\end{array}\right\}$} & $6 \cdot 8$ & $13 \cdot 4$ & $51 \cdot 2$ & 28 & \multirow{5}{*}{$\left.\begin{array}{r}72 \\
100 \\
133 \\
146 \\
167 \\
164 \\
104 \\
141 \\
91 \\
7\end{array}\right\}$} & $17 \cdot 6$ & $25 \cdot 0$ & $70 \cdot 5$ & 46 & 159 & 87 & 38 & 64 \\
\hline & & $5 \cdot 2$ & $16 \cdot 0$ & $32 \cdot 6$ & 23 & & $13 \cdot 1$ & $21 \cdot 5$ & $60 \cdot 9$ & 45 & 152 & 34 & 87 & 96 \\
\hline & & $3 \cdot 2$ & $11 \cdot 2$ & $29 \cdot 6$ & 21 & & $9 \cdot 8$ & $15 \cdot 3$ & $64 \cdot 4$ & 45 & 206 & 37 & 118 & 114 \\
\hline & & $3 \cdot 5$ & $10 \cdot 1$ & $34 \cdot 8$ & 24 & & $9 \cdot 2$ & $14 \cdot 6$ & $63 \cdot 3$ & 42 & 163 & 45 & 82 & 75 \\
\hline & & (2.6) & $(7 \cdot 8)$ & (34) & (21) & & $(8 \cdot 3)$ & $(13 \cdot 5)$ & $(61 \cdot 2)$ & (41) & - & - & - & - \\
\hline & 945 & $4 \cdot 2$ & $12 \cdot 7$ & $33 \cdot 1$ & 23 & 1,125 & $11 \cdot 6$ & $18 \cdot 1$ & 63.9 & 44 & 176 & 43 & 93 & 91 \\
\hline & Trade Gr & un $U$. & skillec & & & & & & & & & & & \\
\hline 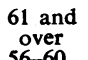 & $\left.\begin{array}{l}370 \\
458\end{array}\right\}$ & $6 \cdot 8$ & $13 \cdot 4$ & $51 \cdot 2$ & 32 & $\left.\begin{array}{c}404 \\
498\end{array}\right\}$ & $19 \cdot 8$ & $24 \cdot 8$ & $79 \cdot 9$ & 51 & 191 & 85 & 56 & 59 \\
\hline $\begin{array}{l}51-55 \\
46-50\end{array}$ & $\begin{array}{l}514 \\
375\end{array}$ & $5 \cdot 7$ & $13 \cdot 0$ & $44 \cdot 1$ & 28 & $\begin{array}{l}547 \\
412\end{array}$ & $15 \cdot 8$ & $21 \cdot 9$ & $72 \cdot 1$ & 48 & 177 & 68 & 63 & 71 \\
\hline $\begin{array}{l}41-45 \\
36-40\end{array}$ & $\left.\begin{array}{l}323 \\
263\end{array}\right\}$ & $4 \cdot 2$ & 11.0 & $38 \cdot 1$ & 24 & $\left.\begin{array}{l}356 \\
287\end{array}\right\}$ & $13 \cdot 2$ & $19 \cdot 8$ & $66 \cdot 7$ & 44 & 214 & 80 & 75 & 83 \\
\hline $\begin{array}{l}31-35 \\
26-30\end{array}$ & $\left.\begin{array}{l}140 \\
101\end{array}\right\}$ & $6 \cdot 0$ & $14 \cdot 6$ & $41 \cdot 1$ & 26 & $\left.\begin{array}{l}169 \\
139\end{array}\right\}$ & $11 \cdot 0$ & $14 \cdot 0$ & $78 \cdot 6$ & 44 & 83 & 0 & 87 & 67 \\
\hline $\begin{array}{l}21-25 \\
20 \text { and }\end{array}$ & $\left.\begin{array}{r}32 \\
4\end{array}\right\}$ & (3.9) & $(7 \cdot 5)$ & $(52 \cdot 8)$ & 22 & $\left.\begin{array}{r}86 \\
7\end{array}\right\}$ & $(10 \cdot 6)$ & $(20 \cdot 1)$ & $(52 \cdot 7)$ & (39) & - & - & - & - \\
\hline & 2,580 & $5 \cdot 7$ & $12 \cdot 8$ & 44.9 & 28 & 2,905 & $15 \cdot 8$ & $21 \cdot 5$ & $73 \cdot 4$ & 47 & 177 & 68 & 63 & 68 \\
\hline & Trade & oup III & Miscella & neous & & & & & & & & & & \\
\hline 61 and & $115\}$ & $7 \cdot 2$ & $20 \cdot 2$ & $35 \cdot 6$ & - & 126 & $16 \cdot 6$ & $26 \cdot 7$ & $62 \cdot 3$ & - & 131 & 32 & 75 & - \\
\hline $\begin{array}{l}56-60 \\
51-55 \\
46-50\end{array}$ & $\left.\begin{array}{l}135 \\
170 \\
130\end{array}\right\}$ & $3 \cdot 6$ & $12 \cdot 6$ & 28.7 & - & $\left.\begin{array}{l}147 \\
187\end{array}\right\}$ & 12.5 & 20.8 & $60 \cdot 0$ & - & 253 & 65 & 109 & - \\
\hline $\begin{array}{l}41-45 \\
36-40\end{array}$ & $\left.\begin{array}{l}126 \\
115\end{array}\right\}$ & $2 \cdot 7$ & $10 \cdot 9$ & 24.9 & - & $\left.\begin{array}{l}154 \\
148\end{array}\right\}$ & $9 \cdot 3$ & $15 \cdot 8$ & 58.9 & - & 244 & 45 & 137 & - \\
\hline $\begin{array}{l}31-35 \\
26-30\end{array}$ & $\left.\begin{array}{l}66 \\
44\end{array}\right\}$ & $2 \cdot 6$ & 6.9 & $38 \cdot 1$ & - & $\left.\begin{array}{l}99 \\
90\end{array}\right\}$ & 11.0 & $15 \cdot 3$ & $72 \cdot 5$ & - & 323 & 122 & 117 & - \\
\hline and & 16\} & $(3 \cdot 3)$ & (9.6) & $(34 \cdot 8)$ & - & $\left.\begin{array}{l}45 \\
12\end{array}\right\}$ & $10 \cdot 2$ & $14 \cdot 2$ & 71.9 & - & (239) & (48) & (107) & - \\
\hline & 924 & $4 \cdot 2$ & 13.7 & $30 \cdot 7$ & - & 1,156 & $12 \cdot 3$ & $19 \cdot 6$ & $62 \cdot 7$ & - & 193 & 43 & 104 & - \\
\hline
\end{tabular}


It will be seen that the present rates for the unskilled trades are higher than those for the skilled trades. Yet the rates for the unskilled workers for the year before the scheme was introduced were also higher. There is little difference in the proportional increase. There is a lower increase among the more elderly in the skilled trades but a higher increase among the younger people. The unskilled show a smaller increase in the number of occasions of absence and a larger increase in the duration of absences. These are crude estimates but support the assumption that the unskilled groups contain a larger number of relatively unfit men. They do contain a higher proportion of registered disabled, and the extraction of these from both groups reduces the disparity to some extent. It may be assumed that they also contain a higher proportion of men who are relatively unfit but who do not choose to register as disabled persons.

The 1949-50 rates for Trade Group III (miscellaneous) are similar to those of the skilled trades. The greater increase shown for the middle age groups, due to lower rates in 1947-48, is of doubtful significance but has not yet been investigated.
It may be concluded that, although the unskilled workers have rather higher absence rates than the rest of the population, the proportional increase of the present rates over those before the sick pay scheme was introduced is no different. There is no evidence to suggest that anything would be gained by paying special attention to this group of workers.

(7) Is the Absence for Workers on "Incentive" Pay Less than that of the Time-worker?-The population was divided into those who were paid on a flat rate or time rate basis and those who received some form of incentive payment. The incentive group included all who received an incentive bonus, piece work rates, group bonus, works bonus, joint contract, and those who varied but were predominantly' on one or other of these incentive types of payment. Table 5 gives the absence rates for these two groups.

It will be seen that the flat rate workers have a markedly higher sick absence rate at all ages; they have a higher proportion of people recording sick absence, a higher number of absences, and a higher average length of absence. The proportional increase in the average number of days lost is

TABLE 5

ANALYSIS OF SICKNESS ABSENCE RELATED TO THE METHOD OF PAYMENT

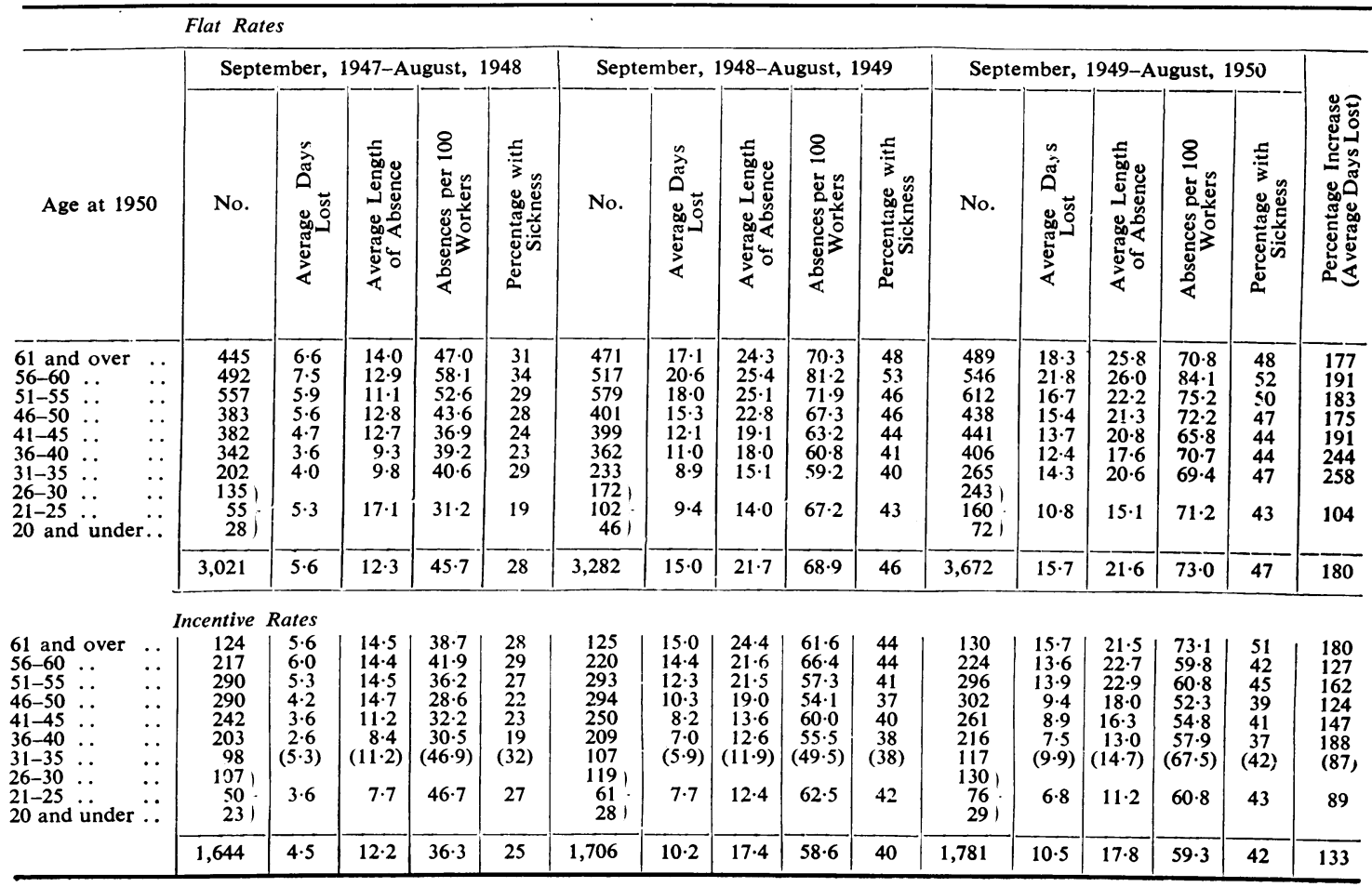


greater at all ages except those of 61 and over where it is much the same.

The population was further divided to compare the effect of flat rate and incentive pay within the groups of skilled and unskilled workers (Table 6). The difference remains distinct and is most marked in the average length of absence. A separate analysis showed the incentive workers to have a higher proportion of absences from one to 10 days and the flat rate workers to have a higher proportion of absences from 11 to 40 days, the greatest difference occurring in absences from 11 to 25 days.
It is interesting to note that the difference between flat-rate and incentive workers is maintained among the new entrants, although the numbers are too small to be reliable.

New entrants on flat rates :

Six months before qualification .. average days lost 3.15 (803 workers)

verage days lost $6.76(638$ Increase $=115 \%$ workers)

New entrants on incentive payment :

Six months before qualification .. average days lost 2.76 (181 " $"$ after, , . average days lost 5.15 (136 Increase $=87 \%$.

TABLE 6

TRADES AND METHOD OF PAYMENT IN RELATION TO SICK ABSENCE RATES

\begin{tabular}{|c|c|c|c|c|c|c|c|c|c|c|c|c|}
\hline \multicolumn{13}{|c|}{ Unskilled Flat Rate } \\
\hline \multirow{2}{*}{\multicolumn{3}{|c|}{ Age at 1950}} & \multicolumn{4}{|c|}{ September, 1947 -August, 1948} & \multirow[b]{2}{*}{$\begin{array}{l}\text { Per- } \\
\text { centage } \\
\text { with } \\
\text { Sickness }\end{array}$} & \multicolumn{5}{|c|}{ September, 1949-August, 1950} \\
\hline & & & No. & $\begin{array}{c}\text { Average } \\
\text { Days } \\
\text { Lost }\end{array}$ & $\begin{array}{l}\text { Average } \\
\text { Length } \\
\text { of } \\
\text { Absence }\end{array}$ & $\begin{array}{l}\text { Absences } \\
\text { per } 100 \\
\text { Workers }\end{array}$ & & No. & $\begin{array}{c}\text { Average } \\
\text { Days } \\
\text { Lost }\end{array}$ & $\begin{array}{l}\text { Average } \\
\text { Length } \\
\text { of } \\
\text { Absence }\end{array}$ & $\begin{array}{l}\text { Absences } \\
\text { per } 100 \\
\text { Workers }\end{array}$ & $\begin{array}{c}\text { Per- } \\
\text { centages } \\
\text { with } \\
\text { Sickness }\end{array}$ \\
\hline \multirow{2}{*}{\multicolumn{2}{|c|}{$\begin{array}{l}56 \text { and over } \\
46-55 . . \\
36-45 \ldots \\
26-35 \ldots \\
25 \text { and under }\end{array}$}} & \multirow[t]{2}{*}{$\begin{array}{l}\cdots \\
\cdots \\
\cdots\end{array}$} & $\left.\begin{array}{r}647 \\
584 \\
401 \\
175 \\
28\end{array}\right\}$ & $\begin{array}{l}7 \cdot 2 \\
6 \cdot 1 \\
4 \cdot 2 \\
5 \cdot 7\end{array}$ & $\begin{array}{l}13.6 \\
12.1 \\
11.8 \\
13.4\end{array}$ & $\begin{array}{l}53 \cdot 2 \\
50 \cdot 4 \\
35 \cdot 7 \\
42 \cdot 4\end{array}$ & $\begin{array}{l}33 \\
30 \\
23 \\
25\end{array}$ & $\left.\begin{array}{r}716 \\
644 \\
449 \\
229 \\
75\end{array}\right\}$ & $\begin{array}{r}21 \cdot 3 \\
17 \cdot 3 \\
15 \cdot 0 \\
12 \cdot 3\end{array}$ & $\begin{array}{l}25 \cdot 6 \\
22 \cdot 3 \\
20 \cdot 8 \\
16 \cdot 7\end{array}$ & $\begin{array}{l}83 \cdot 4 \\
77 \cdot 8 \\
71 \cdot 9 \\
73 \cdot 4\end{array}$ & $\begin{array}{l}55 \\
51 \\
47 \\
41\end{array}$ \\
\hline & & & 1,835 & $6 \cdot 0$ & $12 \cdot 8$ & $47 \cdot 2$ & 29 & 2,113 & $17 \cdot 4$ & $22 \cdot 4$ & $77 \cdot 8$ & 49 \\
\hline
\end{tabular}

Unskilled Incentive

\begin{tabular}{|c|c|c|c|c|c|c|c|c|c|c|c|}
\hline \multirow[t]{2}{*}{$\begin{array}{l}56 \text { and over } . \\
46-55 \ldots \\
36-45 \ldots \\
26-35 \ldots \\
25 \text { and under }\end{array}$} & \multirow[t]{2}{*}{$\begin{array}{l}\cdots \\
\cdots \\
\cdots \\
\cdots\end{array}$} & $\left.\begin{array}{r}181 \\
305 \\
185 \\
66 \\
8\end{array}\right\}$ & $\begin{array}{c}5 \cdot 5 \\
5 \cdot 1 \\
4 \cdot 2 \\
(5 \cdot 9)\end{array}$ & $\begin{array}{r}12.5 \\
15.9 \\
9.5 \\
(13.6)\end{array}$ & $\begin{array}{c}44 \cdot 2 \\
32 \cdot 1 \\
43 \cdot 8 \\
(43 \cdot 2)\end{array}$ & $\begin{array}{c}30 \\
24 \\
29 \\
(28)\end{array}$ & $\left.\begin{array}{r}186 \\
315 \\
194 \\
79 \\
18\end{array}\right\}$ & $\begin{array}{c}14.2 \\
12.7 \\
9.2 \\
(6 \cdot 8)\end{array}$ & $\begin{array}{l}21 \cdot 3 \\
20 \cdot 9 \\
16 \cdot 8 \\
(9 \cdot 6)\end{array}$ & $\begin{array}{c}66 \cdot 7 \\
60.6 \\
54.6 \\
(70 \cdot 1)\end{array}$ & $\begin{array}{r}45 \\
43 \\
36 \\
(42)\end{array}$ \\
\hline & & 745 & $5 \cdot 1$ & $12 \cdot 9$ & $39 \cdot 1$ & 26 & 792 & 11.4 & 18.6 & $61 \cdot 7$ & 42 \\
\hline
\end{tabular}

Skilled Flat Rate

\begin{tabular}{|c|c|c|c|c|c|c|c|c|c|c|c|}
\hline \multirow[t]{2}{*}{$\begin{array}{l}56 \text { and over . } \\
46-55 \ldots \\
36-45 . . \\
26-35 . \\
25 \text { and under }\end{array}$} & \multirow[t]{2}{*}{$\begin{array}{l}\cdots \\
\cdots \\
\cdots\end{array}$} & $\left.\begin{array}{r}77 \\
108 \\
132 \\
83 \\
18\end{array}\right\}$ & $\begin{array}{c}(5 \cdot 0) \\
5 \cdot 2 \\
3 \cdot 4 \\
2 \cdot 9\end{array}$ & $\begin{array}{c}(14 \cdot 7) \\
20 \cdot 2 \\
11 \cdot 1 \\
15 \cdot 3\end{array}$ & $\begin{array}{c}(33.8) \\
25 \cdot 9 \\
30 \cdot 3 \\
18.8\end{array}$ & $\begin{array}{l}(25) \\
20 \\
20 \\
15\end{array}$ & $\left.\begin{array}{r}86 \\
122 \\
154 \\
126 \\
49\end{array}\right\}$ & $\begin{array}{c}(19 \cdot 5) \\
16.7 \\
12 \cdot 1 \\
8.5\end{array}$ & $\begin{array}{c}(28 \cdot 6) \\
26 \cdot 5 \\
17 \cdot 2 \\
14 \cdot 4\end{array}$ & $\begin{array}{c}(67.4) \\
63 \cdot 1 \\
70 \cdot 8 \\
59 \cdot 4\end{array}$ & $\begin{array}{c}(43) \\
46 \\
51 \\
41\end{array}$ \\
\hline & & 418 & 4.02 & 14.9 & $27 \cdot 1$ & 20 & 537 & $13 \cdot 2$ & 20.4 & $65 \cdot 2$ & 44 \\
\hline
\end{tabular}

\begin{tabular}{|c|c|c|c|c|c|c|c|c|c|c|c|}
\hline \multirow{3}{*}{$\begin{array}{l}56 \text { and over } . \\
46-55 . . \\
36-45 . \\
26-35 . \\
25 \text { and under }\end{array}$} & \multicolumn{3}{|c|}{ Skilled Incentive } & & & & \multirow{3}{*}{$\left.\begin{array}{r}86 \\
157 \\
177 \\
119 \\
49\end{array}\right\}$} & & & & \\
\hline & $\begin{array}{l}. \\
\cdots\end{array}$ & $\begin{array}{r}82 \\
150 \\
162\end{array}$ & $\begin{array}{l}6 \cdot 2 \\
5 \cdot 2 \\
3 \cdot 3\end{array}$ & $\begin{array}{l}14 \cdot 5 \\
13 \cdot 9 \\
11 \cdot 3\end{array}$ & $\begin{array}{l}42.7 \\
37.3 \\
29.0\end{array}$ & $\begin{array}{l}30 \\
25 \\
22\end{array}$ & & $\begin{array}{r}15 \cdot 7 \\
10 \cdot 3 \\
7 \cdot 8\end{array}$ & $\begin{array}{l}21 \cdot 4 \\
17 \cdot 4 \\
13 \cdot 2\end{array}$ & $\begin{array}{l}73 \cdot 3 \\
59 \cdot 2 \\
58 \cdot 8\end{array}$ & $\begin{array}{l}49 \\
45 \\
46\end{array}$ \\
\hline & 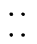 & $\left.\begin{array}{l}98 \\
35\end{array}\right\}$ & 3.7 & $7 \cdot 8$ & $46 \cdot 6$ & 30 & & $9 \cdot 4$ & $14 \cdot 2$ & $66 \cdot 1$ & 43 \\
\hline & & 527 & $4 \cdot 4$ & $11 \cdot 5$ & $38 \cdot 0$ & 26 & 588 & $10 \cdot 1$ & $15 \cdot 9$ & $63 \cdot 1$ & 45 \\
\hline
\end{tabular}

Since these types of incentive payment are made only in nine of the 25 establishments studied, it would be possible for the difference between sick absence rates to be due to the establishments themselves. However, a further analysis was made and revealed that in those establishments with workers both on time and incentive pay, the timepaid workers had a similar sick absence rate to the group of time-paid workers as a whole.
It would seem that a distinct difference can be established between these two groups of workers both in their present rates and in the increase over the rates before the sick pay scheme was introduced. It is highly probable that the difference is due to the fact that the worker who receives incentive payment reverts to his flat or basic rate of pay when sick; he gets more money when at work. The worker on flat rates of pay gets the same money 
whether at work or sick; in many instances he may be better off financially when he is absent sick, apart from any expenses caused by the illness itself. No attempt was made to calculate the relative differences in payments received at work or when sick in these two groups.

It must not however be assumed that the difference between the present sick absence of workers on flat rate and incentive rate is all due to such financial causes. Flat-rate workers include a higher proportion of registered disabled and had higher rates before the scheme. The important difference is the consistently higher increase. For example, if the 1947-48 sick absence of the flat-rate workers is increased by the proportion shown for incentive workers the overall sick absence rate would be about 13.4. Nevertheless, flat-rate workers form the majority of the population, and even a minimum reduction of about two days in an average of 15.7 might still be worth attention.

(8) Do People Take Excessive Sick Absence Just before Leaving?-We collected representative samples of men who had left the establishments during the year September, 1949, to August, 1950. Since a large number of these were men with short periods of service, we compared the average rate of absence for six months before qualification with the rate for a period up to six months in all, for which they were qualified just before leaving.
Many men were not qualified for as long a period as six months before they left, but we were able to calculate the average rate for the group as a whole (and for each separate age group) according to the following method :-

We calculated the number of days during which a man was qualified for sick pay within six months (or 130 days) of leaving and we recorded the number of days sick absence taken in this period. If $Q$ is the sum of the days for which each member of a group was qualified within six months of leaving, and $A$ is the sum of the days lost in this period, then A multiplied by 130 and the result divided by $Q$ is the average number of days lost by the group as a whole for six months of qualified service before leaving.

Table 7 shows this comparison. The figures are given for those who left for the following official reasons :- " Resigned " (also "voluntarily retired" if obviously not for age reasons), "domestic", " marriage", " other work", "leaving district", " dissatisfied ", " disgruntled", " travel difficulties", " redundant ", " termination of temporary employment ", " unsuitable", " no suitable work available", and some other odd reasons. We have not included transfers from one establishment to another, nor have we included those who are stated to have left for medical reasons.

Table 7 clearly shows a disproportionate amount of sick absence in the period immediately before leaving and a disproportionate increase over the rates

TABLE 7

ANALYSIS OF ALL LEAVERS EXCEPT ON MEDICAL GROUNDS AND TRANSFERS

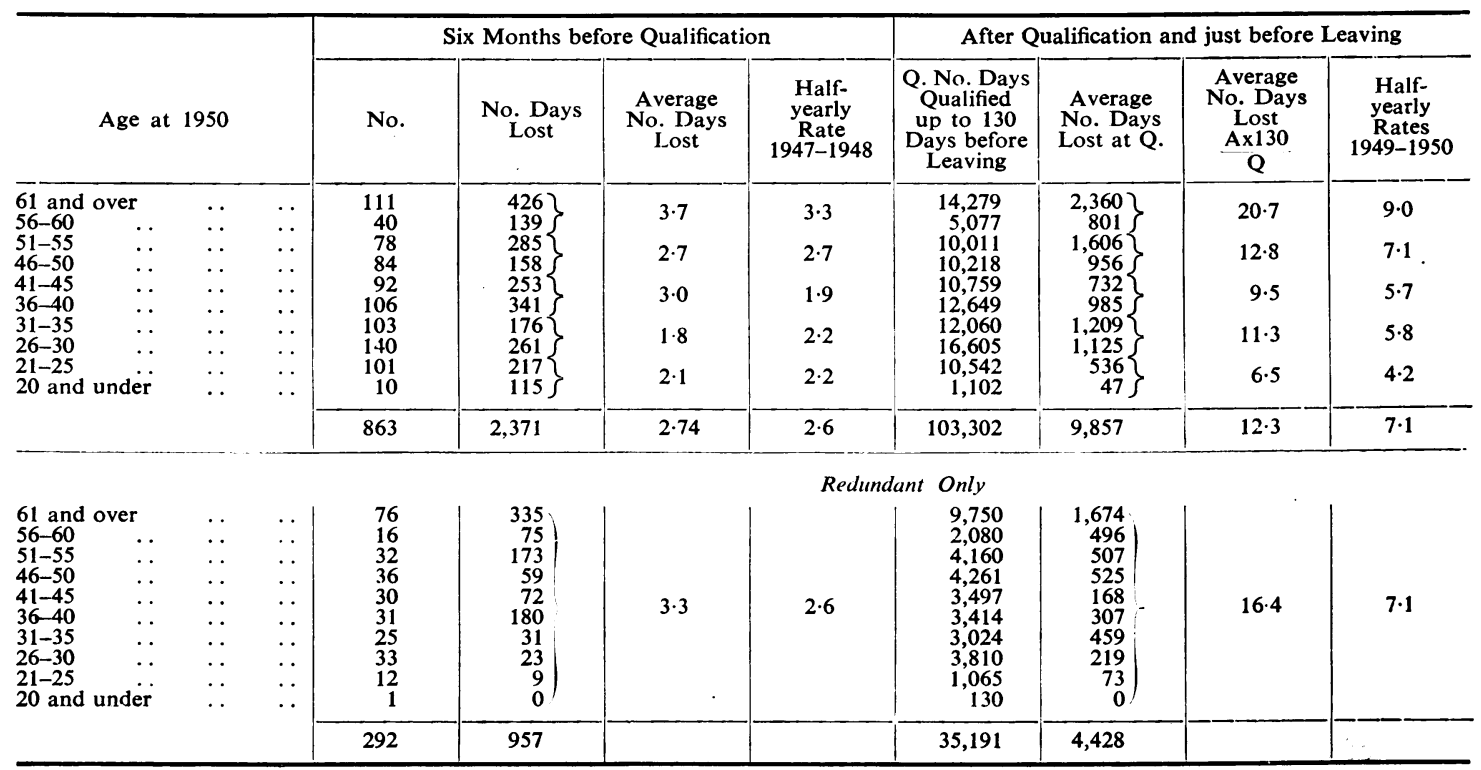


in the six months before qualification. These rates may be compared with half the average rates shown for the whole population in 1949-50. This finding must be interpreted with due caution. The figures do not prove that any of this absence is excessive in the sense of being "unnecessary". Many of these men may have left the establishment for medical reasons, although this may not have been recorded officially among the reasons for leaving. This is particularly likely to be the case among those recorded as having "retired" or " resigned". Others may have decided to leave because recent ill-health had made them wish to change their work, even though it could hardly be said that they had left because they were no longer fit for the work they had been doing. A further group of 136 men, marked simply as "retired", shows an increase from 3.8 days for the six months before qualification to 20.4 days for the six months before retirement. They are all over 61 years old.

Table 7 also shows the rates for men discharged as redundant and, though the numbers are small, a similar disproportionate increase is shown. While this more strongly suggests that men take unnecessary absence before leaving, it is again not proved; it is possible that there is a tendency when declaring men redundant to choose first those who have an unsatisfactory attendance record.

There is certainly a disproportion of sick absence recorded for men about to leave.* It is possible, even likely, that some of this can be regarded as medically unnecessary, but we cannot give a positive statement about it without special study of the detailed records and supplementary studies of sample cases. As the number of leavers is few in relation to total establishment strengths, this problem would only become serious in the event of some future large scale reduction in the number of people employed in Government establishments.

(9) How Does the Sick Absence of Industrial Workers Compare with that of Non-industrial Workers?-Table 8A gives the sick absences for non-industrial workers during the three years from September, 1947, to August, 1950. In the year 1947-48 the sick absence rates of non-industrial workers exceeded those of the industrial workers at all ages; in the next two years the position is reversed. There has, nevertheless, been an increase in the rates for non-industrial workers which is consistent in that it occurs at all ages. This increase may be due to the introduction of the National Health Insurance Scheme in 1948 but, whatever the cause, it is likely to be one which is common to both industrial and non-industrial workers. It is probable that part of the increase in industrial sick absence can be ascribed to other causes than the introduction of the sick pay scheme adone.

The present rates for the industrial population as a whole are higher than those of the non-industrial population, but reference to Table 6 shows that the rates for industrial workers on incentive payment are about the same as those for the nonindustrial workers. The figures for the non-

TABLE 8A

SICK ABSENCE IN NON-INDUSTRIAL WORKERS (TOTAL SAMPLE)

\begin{tabular}{|c|c|c|c|c|c|c|c|c|c|c|c|c|c|c|c|}
\hline \multirow[b]{2}{*}{$\begin{array}{l}\text { Age at } \\
1950\end{array}$} & \multicolumn{5}{|c|}{ September, 1947-August, 1948} & \multicolumn{5}{|c|}{ September, 1948-August, 1949} & \multicolumn{5}{|c|}{ September, 1949-August, 1950} \\
\hline & No. & 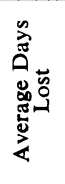 & 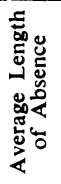 & 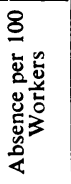 & 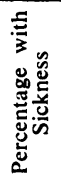 & No. & 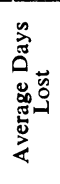 & 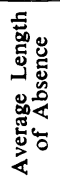 & 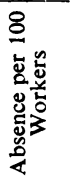 & 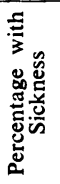 & No. & 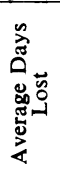 & 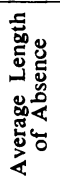 & 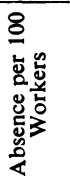 & 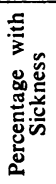 \\
\hline \multirow{3}{*}{$\begin{array}{lr}61 \text { and } & \text { over } \\
56-60 & . \\
51-55 & . \\
46-50 & . \\
41-45 & . \\
36-40 & . \\
31-35 & . \\
26-30 & . \\
21-25 & 0 \\
20 \text { and } & \text { under }\end{array}$} & $\begin{array}{r}156 \\
239 \\
364 \\
310 \\
289 \\
216 \\
131 \\
95\end{array}$ & $\begin{array}{r}11.0 \\
9.6 \\
8.8 \\
7.2 \\
6.1 \\
8.0 \\
4.9\end{array}$ & $\begin{array}{l}7 \cdot 1 \\
6 \cdot 8 \\
6 \cdot 3 \\
5 \cdot 2 \\
4 \cdot 6 \\
4 \cdot 8 \\
3 \cdot 0\end{array}$ & $\begin{array}{l}164.2 \\
140.0 \\
138.5 \\
138.0 \\
132.2 \\
167.6 \\
161.8\end{array}$ & $\begin{array}{l}64 \\
61 \\
63 \\
62 \\
59 \\
69 \\
64\end{array}$ & $\begin{array}{l}166 \\
245 \\
377 \\
320 \\
302 \\
223 \\
137 \\
103\end{array}$ & $\begin{array}{r}12 \cdot 1 \\
13 \cdot 5 \\
10 \cdot 2 \\
7 \cdot 6 \\
8 \cdot 1 \\
8 \cdot 7 \\
8 \cdot 4\end{array}$ & $\begin{array}{l}7 \cdot 7 \\
9 \cdot 1 \\
7 \cdot 0 \\
4 \cdot 8 \\
5 \cdot 6 \\
5 \cdot 1 \\
5 \cdot 0\end{array}$ & $\begin{array}{l}156.6 \\
148.6 \\
146.4 \\
158.8 \\
144.4 \\
172.2 \\
167.2\end{array}$ & $\begin{array}{l}\mathbf{6 6} \\
\mathbf{6 2} \\
\mathbf{6 7} \\
\mathbf{6 7} \\
\mathbf{6 3} \\
\mathbf{7 0} \\
\mathbf{6 5}\end{array}$ & $\begin{array}{l}168 \\
252 \\
388 \\
331 \\
319 \\
233 \\
152 \\
123\end{array}$ & $\begin{array}{r}13 \cdot 2 \\
14 \cdot 1 \\
12 \cdot 3 \\
8 \cdot 2 \\
8 \cdot 8 \\
8 \cdot 6 \\
7 \cdot 4\end{array}$ & $\begin{array}{l}8 \cdot 5 \\
8 \cdot 8 \\
7 \cdot 4 \\
5 \cdot 7 \\
6 \cdot 1 \\
5 \cdot 3 \\
4 \cdot 4\end{array}$ & $\begin{array}{l}155.9 \\
161.5 \\
165.2 \\
144.7 \\
142.6 \\
163.1 \\
169.1\end{array}$ & $\begin{array}{l}65 \\
68 \\
70 \\
61 \\
66 \\
67 \\
68\end{array}$ \\
\hline & 25 & $4 \cdot 4$ & $3 \cdot 0$ & $146 \cdot 3$ & 58 & 30 & 6.7 & $4 \cdot 0$ & 168.7 & 67 & 37 & $7 \cdot 7$ & $4 \cdot 5$ & $169 \cdot 3$ & 71 \\
\hline & 1,826 & $7 \cdot 8$ & $5 \cdot 3$ & $145 \cdot 4$ & 62 & 1,904 & $9 \cdot 5$ & $6 \cdot 1$ & $155 \cdot 4$ & 66 & 2,006 & $10 \cdot 2$ & $6 \cdot 5$ & 157.4 & 67 \\
\hline
\end{tabular}

* Our visits were paid between September, 1950, and March, 1951. In collecting our samples from the present strengths of establishments we will have included some men who would have been near to leaving in the year 1949-50; this may have slightly exaggerated the rates shown in our tables for this year. industrial workers include the short uncertified absences to which they are entitled; there is probably no difference between the cost of nonindustrial sick absence and that of the industrial 
TABLE 8 B

CERTIFIED AND UNCERTIFIED ABSENCE (REDUCED TOTAL)

\begin{tabular}{|c|c|c|c|c|c|c|c|c|}
\hline \multirow[b]{2}{*}{$\begin{array}{c}\text { Age at } \\
1950\end{array}$} & \multicolumn{4}{|c|}{ September, 1947-August, 1948} & \multicolumn{4}{|c|}{ September, 1949-Augus:, 1950} \\
\hline & No. & $\begin{array}{c}\text { Average } \\
\text { Days Lost } \\
\text { Certified }\end{array}$ & $\begin{array}{c}\text { Average } \\
\text { Days Lost } \\
\text { Uncertified }\end{array}$ & $\begin{array}{c}\text { Percentage } \\
\text { with } \\
\text { Uncertified } \\
\text { Absence }\end{array}$ & No. & $\begin{array}{c}\text { Average } \\
\text { Days Lost } \\
\text { Certified }\end{array}$ & $\begin{array}{c}\text { Average } \\
\text { Days Lost } \\
\text { Uncertified }\end{array}$ & $\begin{array}{c}\text { Percentage } \\
\text { with } \\
\text { Uncertified } \\
\text { Absence }\end{array}$ \\
\hline \multirow{3}{*}{$\begin{array}{ll}61 \text { and over } . . \\
56-60 . . & \ldots \\
51-55 . . & \ldots \\
46-50 . . & . \\
41-45 \ldots & . \\
36-40 \ldots & . . \\
31-35 \ldots & . \\
26-30 \ldots & \ldots \\
21-25 \ldots & . \\
20 \text { and under.. }\end{array}$} & $\begin{array}{l}127 \\
178 \\
290 \\
258 \\
230 \\
165 \\
100\end{array}$ & $\begin{array}{r}11.02 \\
9.03 \\
7.86 \\
5.84 \\
5.17 \\
5.13 \\
3.75\end{array}$ & $\begin{array}{l}1.42 \\
1.28 \\
1.28 \\
1.25 \\
1.23 \\
1.58 \\
1.46\end{array}$ & $\begin{array}{l}51 \\
53 \\
52 \\
49 \\
46 \\
61 \\
56\end{array}$ & $\begin{array}{l}138 \\
189 \\
307 \\
274 \\
255 \\
176 \\
111\end{array}$ & $\begin{array}{r}11.49 \\
12.85 \\
10.39 \\
6.73 \\
7.51 \\
6.85 \\
5.54\end{array}$ & $\begin{array}{l}1.08 \\
1.48 \\
1.36 \\
1.27 \\
1.22 \\
1.32 \\
1.50\end{array}$ & $\begin{array}{l}42 \\
52 \\
53 \\
48 \\
49 \\
52 \\
55\end{array}$ \\
\hline & 20 & $3 \cdot 12$ & $1 \cdot 34$ & 52 & $30 !$ & $7 \cdot 42$ & $1 \cdot 53$ & 62 \\
\hline & 1,439 & $6 \cdot 60$ & $1 \cdot 33$ & 52 & 1,568 & $8 \cdot 70$ & $1 \cdot 33$ & 51 \\
\hline
\end{tabular}

workers on incentive payment. (The sample of non-industrial workers includes men in higher executive posts.)

There are, however, considerable differences in the ways in which sick absence is taken. As would be expected, the non-industrial worker takes more frequent short absences and fewer people take no absence at all. Table 8B gives the rates for certified and uncertified sick absence separately. It will be seen that there has been no increase in the average number of days lost from uncertified sickness and no increase in the proportion of people who record uncertified sick absence. Consequently the increase in non-industrial sick absence must have been due to certified sick absence alone.

These figures suggest that we should look for administrative causes following the introduction of the National Health Service as an explanation of at least part of the increase among non-industrial workers and as an explanation of some part of the increase among industrial workers.

\section{Discussion}

We have attempted to get a clearer statistical picture of the sick absence rates and the way in which they have increased after the introduction of the sick pay scheme. We have compared rates between different groups of workers and we have estimated the relative importance of the contribution made by some groups towards the general rate of sick absence. Our chief object has been to discover whether there are any groups of people who contribute more than others to the general increase and whether the total contribution is sufficient to make it worth taking practical steps to remedy the situation.

By this method it has been possible to investigate some of the questions posed by the increase in sick absence without having to resort to comparisons with other industrial organizations. But it should be noted that similar rates of sick absence have been reported by other organizations which have sick pay schemes. We have examined statistics for one factory belonging to a private organization. At this factory half the population were regarded as established workers and received sick benefit on terms similar to those received by Government industrial workers. The sick absence rates for those who received benefit were strikingly higher than the rates for those who did not. The sick benefit scheme had been in operation for many years, and it was shown that the increase took place as soon as men became eligible for sick pay. The difference between the rates of those who did and did not receive sick benefit was of the same order as the difference between the 1947 and 1950 rates at a nearby Government factory which was doing similar work. We think it is unlikely that the present sick absence rates will decline to any marked extent as time goes on. We have found no evidence to support a suggestion that the present sick absence rates are to any extent caused by some deep-seated state of psychological unrest among the working population at the present time.

The increase in sick absence among non-industrial workers can perhaps be explained by the introduction of the National Health Service for the whole country in. 1948. If this were so, the increase among industrial workers could presumably be ascribed in part to this cause as well as to the introduction of the sick pay scheme.

We find no evidence that a sufficient explanation of the general increase is to be found in terms of the age distribution of Government industrial workers, nor that the proportion of registered disabled workers accounts for more than a small fraction of the present rate. We have extracted the proportion of unpaid long-term absence, and 
find that the rate for paid absence still appears formidable compared with the overall rate before the scheme was introduced. There is little evidence that new entrants (in the three years covered by our survey) have contributed any undue amount to the absence rate. We find insufficient difference between the broad classification of skilled and unskilled workers to concentrate the search for remedies on the one class or on the other. There is a high rate of sick absence among those who are about to leave although it is not possible to explain it fully. But the magnitude of this problem is dependent on labour turnover ; it would only be worth attention in the event of some future large scale reduction in the number of men employed.

We do find a distinct and striking difference between workers who receive incentive payment and those who do not. It is possible that part of this difference might arise from selection, the less fit workers gravitating to jobs involving less speed. However, not only the sick rate but the proportional increase in days lost after the introduction of the scheme is lower for the incentive worker, and this suggests that the smaller absence rate of the latter is in part due to the fact that he receives less money when absent sick than when at work. Yet it is unlikely that he is driven to work by dire necessity. We do not believe that this earlier return to work has any ill effects on health, although investigation of this point was beyond the scope of this stage of our enquiry. It is likely, for reasons which will be discussed later, that it may have some beneficial effects on health.

For the time worker the monetary incentive may work the other way round. He receives his full pay when he is absent sick, and he has no travelling expenses ; if he pays income tax, the exemption of that part of his wage which is National Health Insurance may take him out of the tax-paying class ; in some instances he may draw extra benefit from his own sick club or clubs.

The introduction of any sick pay scheme of this kind will enable many people to be absent who ought to have been absent before. Many executive officials stressed this aspect to us, and commented on the number of cases before the scheme where men came to work who ought to have stayed at home. To this extent some increase in sick absence was to have been expected, although it is impossible to estimate how much. But one would expect the increase in "necessary" absence to bear some constant relation to sick absence rates before the scheme was introduced. Where it is found that one group of workers has both a higher rate and a larger proportional increase than another, and where no explanation can be found in terms of age, conditions of work or other causes, we presume, tentatively, that there is unnecessary absence in the group with the higher rate. We use the term "unnecessary absence" deliberately because the adjective implies no condemnation.

With this sick pay scheme a man may remain absent from work until he and his doctor decide that he is fully recovered from an illness. If there is a reasonable incentive to return to work he may well decide that he is fit enough to do so at a relatively early stage. But, if there is no such incentive to return to work, he may both feel and be unwell for a longer time, and many people will display the signs of illness. The patient may be totally unaware of the connexion between his continued illhealth and the lack of an incentive to get well. No amount of exhortation will convince him that his absence is unnecessary.

This raises an important medical aspect of the problem of paid sick absence. When there was a strong financial incentive to remain at work or to return to work as soon as possible, the doctor had the problem of persuading, even "ordering " a sick man to stay at home. In the absence of such an incentive he may have to consider whether a patient should be persuaded to return to work in order to hasten his recovery. To some extent this problem represents a change of attitude on the part of the doctor; he may be aware of it but, in the ordinary way, he has seldom had to take action about it. This adds a medical argument to the need for some tangible incentive to early recovery.

We heard a good deal in the course of our visits about the problem of creating the right morale. Undoubtedly morale affects sick absence rates. But the comments we heard generally implied that an attitude of hostility should be built up towards the suspected malingerer. Although in many cases the judgment of fellow workers against suspected malingerers may be correct, there will be others in which it will be wildly astray. There are illnesses which, in their early stages, present a convincing picture of malingering. An intimidated or overconscientious worker might well be discouraged by overmuch propaganda from seeking treatment in time. There are inherent dangers in this approach and it may lead to suspicion and recrimination and, eventually, to much worse morale. Some malingering is to be expected, but it seems unlikely that conscious malingering contributes much to the total increase. We believe that it is not worth trying to tackle this problem from the point of view that it is to any large extent a reflection of malingering or deliberate abuse. We have little faith 
that remedies based on exhortation or censure will have any permanent effect. If a scheme is unworkable without such measures there is something wrong with the scheme. It is doubtful whether the cost of more elaborate measures against malingering would be repaid even if all malingering were suppressed.

It is outside the scope of this investigation to try to judge whether the generosity of the scheme as it stands is justified by long-term considerations. It may be that increased production and efficiency and better general health will, in the long run, offset the cost of unnecessary absence and justify the continuance of the scheme even as it stands. But it should be possible to devise some modifications which, while preserving the principle of the scheme, would abolish some of the anomalies. A revision of the scheme was in fact suggested involving a good attendance bonus, offset by a small contribution from the worker towards sick pay. It was hoped that this might provide a monetary incentive to refrain from short absences, and it was coupled with a scheme for stricter supervision of longer absences. This particular suggestion was, however, found unworkable by departments.

Some further suggestions were discussed in detail and are summarized here.

The National Insurance certificate, which is used for the sick pay scheme, could be altered to allow the doctor to state that the patient was unfit for the kind of work he had described himself as doing. This would cover one possible cause of unnecessary absence, where a patient, probably in good faith, may misrepresent the nature of his work; for example, he may exaggerate its strenuousness or exposed conditions. We came across instances where this had happened, and such an alteration would allow some check by the employer and might help in finding alternative employment.

We suggested that the certificate could be altered to allow the doctor to state the number of days he considered the man would be off work and that the final certificate of fitness to resume work could often be omitted. Such an alteration would be likely to reduce the length of absences and also reduce attendance at crowded surgeries. We have learned that this alteration was already being considered and has now been introduced.

In view of the dangers of shop stewards' committees or other lay bodies carrying out checks on unnecessary absence, we discussed the possibility of making the payment of benefits for all absences over a certain length automatically dependent on the agreement of the factory medical officer, who would be the authority for continued payment.
While there are difficulties in introducing such a change, when the present scheme is so closely interwoven with the administration of the National Health Service, our estimates suggested that the introduction of the change would not be difficult or costly for the factories themselves. The suggestion really introduced a change in principle by which it would be recognized that the employer should have some say in the disposal of his funds and the patient slightly more obligation to support his claim on the employer. This transference of authority for payment for the longer absences would clear up difficulties of medical etiquette, and the private doctor would be relieved of some of the conflict which faces him when he is asked to accept responsibility towards industry as well as to his patient.

It is a matter of great difficulty to try to assess the effect of any changes in a scheme of this kind on the basis of comparisons made before and after the introduction of the change. It is necessary to wait at least two years to begin to be sure of what is really happening as a result of the change. Other changes, such as those which might be made in the administration of National Health Insurance, or the occurrence of epidemics, would make it necessary to wait even longer.

We strongly recommend that changes should be introduced experimentally by trying them only on some of the establishments and keeping others, performing similar work in similar conditions, as experimental controls.

Problems arising from the introduction of sick pay schemes or of any forms of health insurance are of great importance to industry as a whole, but the investigation of these problems is of still wider interest in as much as they relate to other matters, such as the administration of National Health Insurance. With so large a number of Government establishments, all under very similar systems of administration, there is ample opportunity to investigate these problems more thoroughly, and these opportunities will be largely wasted by the wholesale introduction of one change or another.

\section{Summary}

A scheme for paid sick leave was introduced for Government industrial employees in September, 1948.

Records of sickness absence and other relevant information were collected from samples of the population in 31 Government establishments. Analysis showed the increase in sickness absence in the two years after the scheme was introduced to have been greater in men employed on time rates than in 
those receiving some form of incentive payment. A broad grouping of occupations into skilled or unskilled showed no real difference.

Age was associated with high absence rates, the registered disabled showed higher absence rates, and there was a disproportionate amount of absence taken by those about to leave. In none of these categories were the numbers sufficiently large to make their contribution to the total increase worth special attention.

The present sick absence rates for industrial workers on incentive payment are similar to those of non-industrial workers whose sick pay scheme is of long standing.

Observations made during visits to establishments, and the comments and suggestions of both workers' representatives and of management were taken into account in the conclusions.

This work was carried out under the general direction of Professor Sir Frederic Bartlett, C.B.E., F.R.S.

We are most grateful for the valuable assistance and criticism of Mr. J. W. Whitfield, lecturer in psychology, University College, London.

We have received the utmost cooperation from workers and management in the establishments we visited. We are especially grateful to the officers responsible for the arduous and monotonous task of producing our records and for the care with which this was done. We greatly appreciate the help given by the Ministries concerned.

Finally, we warmly acknowledge the assistance we have received from the Treasury, and would like to thank the two officers who assisted us in examining the records. 